\title{
KOBİ IFRS'den Günümüze Finansal Raporlama Standartlarının Genel Bir Değerlendirmesi
}

\author{
General Investigation of Financial Reporting Standards from \\ IFRS for SMEs to Present
}

\author{
Özkan Sarısoy ${ }^{1}$, İlknur Eskin ${ }^{2}$ \\ 'Dr., Tekirdağ Namık Kemal Üniversitesi, Muratıı Meslek Yüksekokulu, Muhasebe ve Vergi Bölümü, Tekirdağ, Türkiye \\ ${ }^{2}$ Dr. Öğr. Üyesi, Trakya Üniversitesi, Uzunköprü Uygulamalı Bilimler Yüksekokulu, Edirne, Türkiye
}

ORCID: Ö. S. 0000-0002-2226-0191; İ.E. 0000-0003-2306-7315

\section{ÖZ}

Özünde bir kayıt tekniği olan muhasebe, faaliyetlerini belirli ilkeler dahilinde gerçekleştirmektedir. Bu ilkeler muhasebenin sosyal bir bilim olması ile de ilgili olarak oluşan ihtiyaçlara göre tanzim edilmektedir. Köklü bir tarihe sahip olan muhasebe faaliyetinin, günümüzde kullanılan şekline ulaşmasında özel müteşebbislerin ticari hayat içerisindeki etkisinin arttı̆̆ 18. yüzyı önem arz etmiştir. Özellikle 20. yüzyılın sonlarına doğru işletmelerin küreselleşmesinin de etkisiyle uluslararası yeknesak ilkelerin oluşturulması konusunda çalışmalar gerçekleştirilmiş ve günümüzde birçok ülkede uygulama alanı bulunan Uluslararası Finansal Raporlama Standartları (IFRS-IAS) ile muhasebe de yeni bir döneme girilmiştir. Bununla birlikte IFRS'ler genellikle kamu yararını ilgilendiren kuruluşların (KAYIK) ihtiyaçları dikkate alınarak oluşturulduğu için daha küçük boyuttaki işletmelerin ihtiyaçları için uygun bulunmamıştı. Bu amaçla önce KOBI'ler için IFRS seti yayınlanmış ancak bu set maliyet ve ihtiyaca uygun olmama gibi nedenlerle uygulanamamıştır. Daha sonra BOBİ FRS ve 2021'de uygulanmak üzere daha kü̧̈ük işletmeler için KÜMİ FRS taslağı yayınlanmıştır. Bu araştırmada söz konusu üç standart setinin oluşum süreci ve standart setleri arasındaki farklar incelenerek genel bir değerlendirme yapılmıştır.

Anahtar kelimeler: KOBİ IFRS, BOBİ FRS, KÜMİ FRS

\section{ABSTRACT}

Accounting, which is essentially a recording technique, carries out its activities within certain principles. With the effect of accounting being a social science, these principles are formed by considering the accounting activities needs. Accounting activity has a deep-rooted history, but it had transformed into its current role with the 18th century when private businesses' influence in commercial life was increased. Especially towards the end of the 20th century, studies were carried out on establishing international uniformed principles with the effect of the globalization of businesses. Today, accounting has entered a new era with International Financial Reporting Standards (IFRS), which have applications in many countries. However, since IFRSs are generally created, considering the needs of organizations that concern the public interest, they have not been suitable for smaller businesses. For this aim, the IFRS for SMEs set was published, but this set could not be applied for reasons such as cost and the unsuitability of small business characteristics. Afterward, 'Financial Reporting Standard for Large and Medium-Sized Enterprises (BOBI FRS)' was published recently, and the 'Financial Reporting Standard for Small and Micro Enterprises (KÜMI FRS)' draft was published for the implementation of smaller businesses in 2021. In this research, the formation process of these three sets of standards (IFRS for SMEs, BOBİ FRS, and KÜMİ FRS) were examined, and the differences between them were revealed, and a general evaluation was made.

Keywords: IFRS for SMEs, BOBİ FRS, KÜMİ FRS

Başvuru/Submitted: 15.05.2020 Revizyon Talebi/Revision Requested: 01.06.2020 Son Revizyon/Last Revision Received: 20.07 .2020 Kabul/Accepted: 08.10.2020 Sorumlu yazar/Corresponding author: Özkan Sarısoy / osarisoy@nku.ed.tr

Atıf/Citation: Sarisoy, O. ve Eskin, I. (2021). KOBİ IFRS'den günümüze finansal raporlama standartlarının genel bir değerlendirmesi. Muhasebe Enstitüsü Dergisi - Journal of Accounting Institute, 64, 19-37. https://doi.org/10.26650/MED.738086 


\section{Extended Abstract}

The accounting activity, which deals with monetary events belonging to an economic unit, handles these events according to various regulations, and these arrangements may differ according to the countries. Changes in the business structure from past to present have affected accounting, and new tasks such as analysis and the interpretation of results have been added to the accounting activity. These changes, naturally, were reflected in the accounting principles and caused the existing regulations to be changed. International Financial Reporting Standards (IFRS-IAS), which have an essential place among these principles, are applied in many countries.

Compared with western countries, accounting developments in Turkey are known to have started late and progressed slowly. The developments took place towards especially the end of the 20th century, and continued into the beginning of the 21st century, causing essential accounting changes. The scope of IAS-IFRS applications has been extended with the enforcement of the Turkish Commercial Code. However, since the IFRS set was prepared to consider the institutions of public interest, these standards were admittedly complicated and costly for other businesses that do not fall within these limits and make up about $99 \%$ of commercial life. For this reason, IFRS for SMEs has been created by considering the needs of businesses other than full set standards. However, this standard set planned to be implemented in 2013 was repealed without being implemented.

Nevertheless, the 'Financial Reporting Standard for Large and Medium-Sized Enterprises (BOBİ FRS)' and finally the 'Financial Reporting Standard for Small and Micro Enterprises (KÜMİ FRS)' draft takes into account the size of the business has been published recently. It is a matter of curiosity whether the BOBİ FRS and KÜMİ FRS that were put forward will meet this need. Similarly, the extent to which the concerns arising in IFRS for SMEs are considered in KOBI FRS and BOBİ FRS is considered worth researching. In this research, after giving general information about IFRS for SMEs, BOBİ FRS, and KÜMİ FRS, similarities and differences between these three sets of standards were examined.

IFRS for SMEs has been discussed in many studies during the 2010-2012 period. Afterward, the 'local financial reporting process' by KGK and the publication of the BOBI FRS provided many types of research on this subject. Similarly, the draft KÜMI FRS has been the subject of some research.

Some of the studies related to IFRS for SMEs have generally been compared with full set standards, while in some studies accounting on standards basis has been handled. For example, Utku and Gürsoy (2011), Eskin (2013), Gönen and Demir (2012). However, İğde (2013), Fidan and Cinit (2013), Kılıç and Uyar (2017) investigated the perceptions of the parties regarding IFRS for SMEs.

Similarly, a large part of the work carried out for the BOBİ FRS was shaped around the comparison with an IFRS. For example; Gökçen et al. (2018), Selvi and Ercan (2018), Çalış and Hışman (2019), Karahan and Ayvalığlu (2019), etc. Kırkık et al. (2019), Ergi and Güleç (2019) presented the perspectives of the parties towards the financial reporting standards.

Researches carried out for KÜMİ FRS has been revealed by making comparisons in terms of BOBİ FRS, full set standards, and tax laws with a similar perspective. With this approach, Gökçen et al. (2019), Gençoğlu (2020), and Şen and Özbirecikli (2020) have presented similar studies.

In this study, the historical development processes of the IFRS for SMEs, BOBİ FRS, and KÜMİ FRS draft, which was handled for different reasons but similar purposes, were discussed, and the contents of the standard sets were examined comparatively. In this research, which is handled with the content analysis method, the similar sections in all three standard sets were examined, and differences were revealed with similarities.

According to the research results, although there are similarities between standards according to IFRS for SMEs, there are significant differences. Nevertheless, BOBİ FRS and KÜMİ FRS are more similar. Besides, methods that are easy to account for were generally addressed in KÜMİ FRS. Also, simplicity and understandability were provided by including the issues needed by small and micro-enterprises. Moreover, it is thought that this process will affect members of the profession 
in the future. The issue of how to apply and control KÜMI FRS is also among the issues that cause concern. With these developments, international standards' penetration has expanded, and the transition from tax-based legal regulations to international standards based on information was provided. Although it is accepted that it has lagged behind the west in accounting in the past, Turkey's recent developments show that modern practices in accounting are concurrently being taken into consideration. 


\section{Giriş}

Ekonomik birime ait parasal olaylarla ilgilenen muhasebe faaliyetinin söz konusu olayları ne şekilde ele alacağı çeşitli düzenlemelerle belirlenmekte ve bu düzenlemeler ülkelere göre farklılık arz edebilmektedir. Bu düzenlemelerin bir kısmı yasalarla zorunlu tutulurken bir kısmı öneri şeklinde sunulmaktadır. Zaman zaman adı; kanun, standart, ilke, yönerge vb. isimlerle ifade edilmekle birlikte söz konusu düzenlemelerin ortak amacı muhasebede benzer bir uygulama ortamı yani standardizasyonun sağlanabilmesidir. Bu bağlamda muhasebe standartları, muhasebenin hangi nitelikteki işlemleri ve olayları, hangi değerler üzerinden kaydedeceğini, sınıflandıracağını ve hangi raporlar aracılığı ile sunacağını belirlemeye imkân tanımaktadır (Şensoy, 2008, s. 7).

Geçmişten günümüze işletmelerin doğasındaki değişimler muhasebeyi de etkilemiştir ve zamanla muhasebenin klasik fonksiyonlarının yanında, muhasebeye yapılan işlemlerin ve sonuçların analizi ve yorumlanması gibi görevler de yüklenmiştir (Ayc1, 2012, s. 27). Bu değişimler muhasebe düzenlemelerine de yansıyarak mevcut standartlar değiştirilmiş ya da yeni bazı standartlar eklenmiştir. Ayrıca işletmelerin zamanla küreselleşmesi, sermaye hareketlerinin hızlanması gibi nedenlerle de ortak bir dil oluşturulabilmesi amacıyla uluslararası standartlar yayınlanmıştır. Bu standartlar arasında en yaygın olanı 'Uluslararası Finansal Raporlama Standartları (IFRS-IAS)' dünyanın birçok ülkesinde uygulamaya girmiş ya da birçok ülkede de uyum çalışmaları sürdürülmektedir.

Ülkemiz özelinde muhasebeye ilişkin gelişmelerin batı ülkeleri ile kıyaslandığında daha yakın zamanda meydana geldiği bilinmektedir. Özellikle 20. yüzyılın sonlarına doğru başlayan bu gelişmelerde, dünyanın farklı ülkelerindeki uygulamalar dikkate alınmış ve uluslararası raporlama standartlarının etkisinde kalınmıştır (Ağca ve Aktaş, 2007, s. 5-6). Türkiye’de ilk IAS çevirileri, İstanbul Üniversitesi, İşletme Fakültesi, Muhasebe Enstitüsü tarafından 21 standardın çevrilmesi suretiyle olmuştur (Muhasebe Enstitüsü, 2020). Daha sonra çeviriler 2002 yılında yapılan resmi anlaşma sonrasında Türkiye Muhasebe Standartları Kurulu (TMSK) tarafından gerçekleştirilmiştir. Yapılan çeviriler, ilgili kurum ve kuruluşların görüşüne sunulmuş ve ilgili düzenlemelerle birlikte Türkiye Muhasebe Standartları ismi ile son şekli verilmiştir (Yalkın, Demir ve Demir, 2006, s. 286). TMSK tarafından yayınlanan standartlar 2006 yılının başından itibaren yürürlüğe girmiştir (Hatipoğlu, 2009, s. 86). İlerleyen süreçte 2012 yılında yürürlüğe giren 6102 sayılı Türk Ticaret Kanunu'nda (TTK) defter tutuma sorumluluğunda olan gerçek ve tüzel kişi tacirlerin finansal tablolarını Kamu Gözetimi Muhasebe ve Denetim Standartları Kurumu (KGK) tarafından yayınlanan TFRS’ye uygun hazırlaması gerektiği belirtilmiştir. Bu düzenlemeyle KGK'ya, IFRS'leri Türkçeye tercüme ederek yayınlama ve standartları uygulayacak şirketleri belirleme yetkisi verilmiştir.

Halka açık ve organize borsalarda işlem gören işletmeler için hazırlanan IAS ve IFRS setinin kapsamlı olması nedeniyle, kamuya hesap verme yükümlülüğü bulunmayan, sadece diş paydaşlar için genel amaçlı finansal tablo yayınlama zorunlulukları olan KOBİ'ler için ayrı IFRS seti oluşturma ihtiyacı ortaya çıkmıştır. Bu ihtiyaca bağlı olarak da KOBİ IFRS oluşturulmuştur. Ülkemizde 2013 yılında uygulamaya girmesi planlanan bu standart seti uygulanamadan yürürlükten kaldırılmış ve 2017 yılında işletme büyüklükleri dikkate alınarak hazırlanan BOBİ FRS yayınlanmıştır. Son olarak finansal raporlama çerçevelerine uyumu sağlamak amacıyla küçük ve mikro işletmeler için KÜMİ FRS taslağı yayınlanmıştır.

Bu araştırmanın temel amacı uygulamaya girmeyen KOBİ IFRS ile BOBİ FRS ve KÜMİ FRS setleri arasındaki farklılıkları inceleyerek, genel bir değerleme yapmaktır. Bu amaç doğrultusunda birinci bölümde KOBİ IFRS, BOBİ FRS ve KÜMİ FRS setlerinin oluşum süreci açıklanmış, ikinci bölümde standartlarla ilgili literatür özetlenmiş ve üçüncü bölümde söz konusu üç standart setindeki hükümler bölüm bazında karşılaştırmalı olarak incelenmiştir. Sonuç bölümünde ise çalışmanın genel değerlendirilmesi yapılmıştır.

\subsection{KOBİ IFRS}

IFRS'ler uygulama alanı bulduğu ülkelerde olduğu gibi ülkemizde de belirli büyüklükteki işletmeler için uygulanması zorunlu standart seti olarak yasal mevzuata dahil edilmişlerdir. Ancak IAS ve IFRS setinin karmaşıklığg ve küçük ve orta büyüklükteki işletmelerin kapasitelerinin bu standartları uygulaması önündeki engeller bu standartlar dışında başka standartların yayınlanması gereğini doğurmuştur. 
$\mathrm{Bu}$ yaklaşımla IFRS'lerin, KOBI'lerin ihtiyaçlarını karşılamada karmaşık ve zor gelmesi, KOBİ'lerin gereksinimlerine cevap veren ancak tam setin genel ilkelerine uygun daha basit bir standart seti yayınlanması ihtiyacını gündeme getirmiştir (Akdoğan, 2010, s. 2). KOBi் finansal tablolarının kullanıcıları, tam seti kullanan işletmelerin finansal tablo kullanıcılarının aksine bazı bilgilere ihtiyaç duymamaktadır. Örneğin, uzun vadeli nakit akışları, kar zarar durumu ve şirket değeri ile bilgilere KOBİ finansal tablo kullanıcılarının gereksinim duymayacağından hareketle oluşturulması planlanan yeni standart setinde yer verilmemesi düşünülmüştür (Çetinkaya, 2010, s. 8). Uluslararası Muhasebe Standartları Kurulu (IASB), 2001 yılında KOBİ'ler için uygun muhasebe standartlarının oluşturulması üzerinde çalışmış ve 2003'te standartların geliştirilmesine başlanmıştır. 20 ülkede 116 KOBİ üzerinde yapılan saha testleri 2007'de tamamlanmış ve standartlar 2009 yılında yayınlanmıştır. Sürecin bu kadar uzun olması standardın çok geniş bir kesimin beklentilerini karşılayabilecek açıklıkta hazırlanma gereğinden kaynaklandığı ileri sürülmüştür (Çelik, 2010, s. 43). Söz konusu gelişmeler ülkemizde de yaşanmış ve TTK'da aşağıdaki düzenlemeyle, belirtilen işletmeler KOBİ IFRS uygulamakla yükümlü tutulmuşlardır (6102 Sayılı TTK, Geçici Madde 1):

- Bu maddenin ikinci fikrasının (a) bendinde belirtilenlerin dışında kalan ve işletme yönetiminde yer almayan işletme sahipleri, işletmeye borç verenler ve kredi derecelendirme kuruluşları gibi dı̧̧ kullanıclar için genel amaçll finansal tablo düzenleyen işletmeler.

Genel olarak tam set IFRS ile kıyaslandığında, KOBİ IFRS'ye bazı unsurlar dahil edilmemiş, politika seçimlerinde daha basit seçeneklere yer verilmiş ve daha az açılama yapılması zorunlu tutulmuştur. Türkiye'de ilk etapta standardın 1 Ocak 2013 'ten sonra başlayan hesap dönemlerinden itibaren kullanılması planlanmış ancak gerekli eğitimlerin tamamlanamaması nedeniyle uygulama ertelenmiştir (İğde, 2013, s. 133). Ancak günümüze değin KOBİ IFRS'ler uygulama alanı bulamamıştır. Bu süreçte Avrupa ülkelerinde de benzer şekilde gerçekleşmiş, Avrupa Komisyonu, KOBİ IFRS’nin yönetim maliyetlerini arttıracağı ve finansal raporlama uygulamalarını basitleştirmeyeceği gerekçesiyle standart setini kabul etmemiş ve KOBİ IFRS'nin sadeleştirilmesi ve gözden geçirilmesi projesini başlatııştır (Demir ve Bahadır, 2014, s. 15).

\subsection{BOBİ FRS}

KOBİ IFRS'lerin uygulanamadan yürürlükten kaldırılması ile KAYİK kapsamı dışında kalan işletmeler Muhasebe Sistemi Uygulama Genel Tebliği’ni (MSUGT) uygulamak zorunda kalmışıtır. Ancak KAYİK olmamakla birlikte bağımsız denetime tabi olan işletmeler bakımından bu husus bazı sakıncalar doğurmuştur. Her ne kadar "TMS'leri Uygulamayan Şirketlerin Finansal Tablolarının Hazırlanmasında Uygulanacak Ilave Hususlar" ile (2014) bazı eklemeler yapılarak eksiklikler giderilmeye çalışılsa da mevzuatın vergi odaklı yapısı ihtiyacı karşılayamamıştır (Gökçen, Öztürk ve Güleç, 2018, s. 440). Daha sonraki süreçte KGK tarafından 'Yerel Finansal Raporlama Çerçevesi (YFRÇ)' taslağı paylaşılarak, kamuoyu görüşüne sunulan bu girişimde KAYİK dışındaki işletmelerin tam setlerin maliyetine katlanmadan ihtiyaç duydukları standartların hazırlanması perspektifinden hareket edilmiştir (Tekbaş, 2015).

Avrupa Birliği’nin (AB) genelinde de benzer süreçler yaşanmıştır. KOBİ IFRS'nin değiştirilmesi ve yeni bir standart setinin hazırlanması projesi AB'nin 2013/34 nolu direktifine dayanmaktadır (2013/34/EU Directive). Bu direktifte dikkate alınan şirket türleri; anonim, limited ve sermayesi paylara bölünmüş komandit şirket olarak belirlenerek belirli kriterler (aktif büyüklüğü, net satışlar ve çalışan sayıları) dikkate alınarak işletme büyüklüklerine ilişkin belirli sıralamalar (mikro, küçük, orta ve büyük işletmeler) yapılmıştır (Gökçen ve ark., 2018, s. 439). Bu yeni sınıflandırma ile daha önce küçük ve orta büyüklükte (KOBİ) olmak üzere iki ölçekte ele alınan işletmeler, dört farklı ölçekte sınıflandırılmıştır. Bu standart seti AB'nin genelini kapsamamakla birlikte, İngiltere ve İrlanda'da FRS 102 kodu ile yayınlanan standart seti Türkiye'de BOBİ FRS sürecinde dikkate alınmıştır (Altıntaş ve Parlak, 2018, s. 540). BOBİ FRS 2017 yılında yayınlanarak 2018 yılında başlayan finansal raporlama döneminden itibaren geçerli olmak üzere yürürlüğe girmiştir (30138 Sayılı Resmi Gazete, 29.07.2017). BOBİ FRS ile tam set standartları uygulamamakla birlikte bağımsız denetime tabi olan işletmelerin ihtiyaca uygun ve karşılaştırılabilir finansal tablolar sağlaması amaçlanmıştır. 


\subsection{KÜMI FRS}

Küçük ve orta büyüklükteki işletmelerin ekonomik sistem içerisindeki önemine binaen KAYİK ve büyük işletmelerin yanında küçük ve mikro büyüklükteki işletmeler için de finansal raporlama standartlarının oluşturulması gündeme gelmiş̧ir. Daha önce KAYİK dışındaki işletmeler KOBİ sınırları ile genel bir ölçekte ele alınmış ve standartlar (KOBİ IFRS) bu yaklaşımla hazırlanmıştır. Ancak KAYİK olmayıp bağımsız denetim tabi olan büyük işletmelerin dışında KOBI sınıfına giren işletmeler arasında da önemli farklılıklar bulunmaktadır. Bu yaklaşımla bu sınıflandırmadan vazgeçilerek dört alt sınıflama yapılmıştır. AB direktifinde yer alan bu sınıflandırma, işletmelerin çeşitli açılardan büyüklüklerini ifade etmektedir. Küçük işletmelerin orta büyüklükteki bir işletmeye göre daha dar çıkar çevresine sahip olması, teknik ve mali imkânları, işletmelerin yapısına uygun standartların oluşturulmasını sağlamıştır.

Muhasebenin bilgi verme fonksiyonunun 19. yüzyıldan itibaren büyük işletmelerin çoğalması ile arttı̆̆ı ileri sürülür. Bu nedenle 19. yüzyıldan önce işletme sahiplerinin finansal durumlarına ilişkin kamuya önemli bildirimlerde bulunmadığ kabul edilmektedir (Kumar ve Mohan, 2015, s. 44). Bu nedenle işletmenin büyüklüğüne bağlı olarak işletmeden bilgi ihtiyacı duyan kesimler çoğaldıkça finansal raporlamanın önemi artmıştır. Bununla birlikte günümüzde küçük işletmeler için gerek yasal düzenlemelerin artması gerekse işletmelerin çıkar çevresinin genişlemesi gibi nedenlerle küçük işletmeler için bir takım bildirimler yapmak önemli ve zorunlu hale gelmiştir.

AB direktifinde küçük işletmelerin de vurgulanmasından hareketle İngiltere'de küçük işletmeler için FRS 105 kodu ile finansal raporlama standartları yayınlanmıştır. Bu standart seti ile küçük işletmeler için gerekli olan düşük maliyetli ve şeffaf raporlamanın sağlanması amaçlanmıştır. FRC standartlar Genel Müdürü McLaren tarafından FRS 105 ile İngiltere'de 1,5 milyona yakın küçük işletmenin muhasebe gereksinimlerinin daha da basitleştirildiği dile getirilmiştir (www.frc.org.uk).

Bu yaklaşım tarzıyla Türkiye'de de KGK, bağımsız denetime tabi olmayan işletmeler için gerçeğe ve ihtiyaca uygun ve karşılaştırılabilir finansal tabloların hazırlanabilmesi amacıyla KÜMİ FRS taslağını yayınlamışıı. KGK'nın 12 Temmuz 2019'da yayınlamış olduğu KÜMİ FRS taslağının 2021 yılından itibaren uygulanması öngörülmektedir. KGK'nın belirli hususlara ilişkin görüş talep ettiği KÜMİ FRS'nin uygulamaya girmesi ile aşağıdaki faydaların sağlanacağı düşünülmektedir (www.kgk.gov.tr).

- Türkiye ekonomisinde yer alan çok sayıdaki küçük ve mikro ölçekteki işletme için gerçeğe ve ihtiyaca uygun sunum ile karşılaştırılabilirlik ilkeleri tabana yayılmış olacaktır.

- Kü̧̈ük ve mikro ölçekteki işletmelerin; yatırımcı ve borç verenlere, gerçeğe ve ihtiyaca uygun finansal bilgi ile karşılaştırılabilir finansal tablo sunmaları sağlanacak, böylelikle işletmelerin düşük maliyetli kredi ve fon temin etme sürecinde yaşanan zorluklar büyük oranda giderilecektir.

- Vergi esasl muhasebe anlayışından, bilgi esaslı muhasebe anlayışına geçecek olan küçük ve mikro ölçekteki işletmelerin alacakları kararlar işletme düzeyinde kaynak dağıllmının etkinliğini sağlayacaktır.

- Gerçeğe ve ihtiyaca uygun bilgi sunan finansal tablolar, işletme yöneticilerinin işletmelerin gerçek durumunu doğru değerlendirmelerini ve rasyonel kararlar almaların sağlayarak işletmelerin kurumsal yapılarının gelişim sürecine olumlu bir katkı sağlayacaktır. Bu durum ise, ülkemiz işletmelerinin kurumsal yapısını güçlendirerek, daha sağllkll, geniş katılımlı ve uzun vadeli ortaklık yapılarının oluşmasını sağlayacaktır.

KGK, KÜMİ FRS'yi hazırlama sürecinde; FRS 105, KOBİ IFRS, 2013/34/EU direktifi, MSUGT, 213 nolu VUK ve diğer ülke uygulamalarını dikkate almıştır (KÜMİ FRS Semineri, 2019, s. 8). Bu düzenleme ile AB ve diğer uluslararası uygulamalarla uyum sağlanmıştır (Kıymetli Şen ve Özbirecikli, 2020, s. 15). Bununla birlikte KÜMİ FRS'ye ilişkin uygulamada aşağıdaki zorluklarla karşılaşılabileceği de ifade edilmektedir (KÜMİ FRS Semineri, 2019, s. 23). 
- Vergi temelli yaklaşımın değiştirilmesi

- Uygulamanın kontrolü ve denetimi

- Yeni sistemin uygulanmasinın maliyeti

- Küçük ve mikro işletmeler için hükümlerin ayrılması gerekip gerekmediği

- Dipnotların kapsamı

- Borçlanma maliyetlerinin finansal tablolara alınması

\section{Amaç ve Yöntem}

2013 yılında uygulanması planlanan ancak, o dönem itibariyle, maliyet ve teknik yetersizlik (standartları uygulayacak işletmeler bakımından) gibi nedenlerle rafa kaldırılan KOBİ IFRS, yakın tarihimizde uygulamaya giren BOBİ FRS ve taslağı sunulan KÜMI FRS olarak iki farklı standart seti ile yeniden ele alınmıştır. Bu yaklaşım tarzından hareketle ortaya konan BOBİ FRS ve 2021 yılı itibariyle uygulamaya girmesi beklenen KÜMİ FRS ile finansal raporlamada standartlaşmanın kapsamı genişletilmiştir. Bu araştırmada uygulamaya girmeden yürürlükten kaldırılan KOBİ IFRS ile BOBİ FRS ve KÜMİ FRS karşılaştırılarak temel farklılıklar incelenmiştir. Bu amaçla üç standart setinde de yer verilen bölümler genel hatları ile ele alınmıştır.

\subsection{Literatür İncelemesi}

KOBİ IFRS, tartışıldığ 2010-2012 sürecinde birçok araştırmada ele alınan bir konu olmuştur. Daha sonra KGK tarafından YFRÇ süreci ve ardından BOBİ FRS'nin yayınlanması bu konuda birçok araştırmanın yapılmasını sağlamıştır. Benzer şekilde KÜMİ FRS taslağı da bazı araştırmalara konu olmuştur. Araştırmanın bu kısmından söz konusu üç standart setine ilişkin yapılan bazı çalışmalar özetlenmiştir.

KOBİ IFRS'lere ilişkin araştırmaların bir kısmı genel olarak tam set standartlarla mukayeseyi ele almıştır, bazı araştırmalarda ise standartlar bazında muhasebeleştirme incelenmiştir. Örneğin; Utku ve Gürsoy (2011), Eskin (2013), Gönen ve Demir (2012). Bununlar birlikte İğde (2013) standartlar hakkında genel bir değerlendirme yapmış ve KOBİ IFRS'ye yönelik meslek mensuplarının görüşlerini incelemiş ve sonuç olarak meslek mensuplarının KOBİ IFRS konusunda kararsız olduklarını belirtmiştir. Fidan ve Cinit (2013) ise, tam set standartlar ve KOBİ IFRS'ye ilişkin meslek mensuplarının algılarını araştırmış ve sonuç olarak mesleki tecrübenin standartlara ilişkin algıları etkilediğini tespit etmişlerdir. Kılıç ve Uyar (2017), akademisyenlerin ve muhasebecilerin görüşlerine dayanarak, KOBİ IFRS'nin uyum sürecini araştırmışlardır. Söz konusu çalışmada; IFRS’nin hem borsada işlem gören hem de işlem görmeyen şirketlerin ihtiyacını karşılamadığı için, KOBI’lere yönelik ayrı bir standart setine ihtiyaç duyulduğu belirtilmiştir. Ayrıca çalışma, eğitimli personel eksikliğini, Türk muhasebe meslek mensuplarının kural bazlı uygulamalardan ilke bazlı finansal raporlama standartlarına geçişte yaşayacağ zorlukları vurgulamıştır.

BOBİ FRS'ye yönelik gerçekleştirilen çalışmaların büyük bir bölümü tam set standartlarla mukayese etrafında şekillenmiştir. Gökçen ve ark. (2018) BOBİ FRS ve tam set standartları finansal raporlara etkisi bakımından karşılaştırmalı olarak incelemişlerdir. Çalışmada, BOBİ FRS’ye göre oluşturulan finansal raporların gerçeğe uygun nitelikte finansal bilgi sunamadığı belirtilmiştir. Selvi ve Ercan (2018) BOBİ FRS’ye göre stoklara ilişkin muhasebe ilkelerini tam set standartlar ve VUK hükümleri ile mukayese ederek incelemişlerdir. Benzer şekilde Çalış ve Hışman (2019) hasılat standardı kapsamında karşılaştırma yapmışlardır. Karahan ve Ayvalıoğlu (2019) karşılaştırmayı finansal kiralama işlemleri bakımından ele almışlardır. Yıldırım (2019) ise, araştırmasında karşılıklar standardını incelemiştir. Küçük (2018), BOBİ FRS'ye göre devlet teşviki kapsamındaki düşük faizli kredileri değerlendirerek önerilerde bulunmuştur. Karaömer ve Özbirecikli (2019) BOBİ FRS'ye göre hazırlanan finansal tablolardan hareketle finansal rapor oranlarını incelemiş ve VUK ile kıyaslama yaparak sonuçların farklılığını ortaya koymuşlardır. Kırkık ve ark. (2019) SMMM’lerin BOBİ FRS'ye bakış açıklarını incelemişlerdir. 
Çalışmada, muhasebe meslek mensuplarının BOBİ FRS'nin işletmenin şeffaflaşmasına ve kurumsallaşmasına olumlu yönde katkı sağlayacağına ve daha güvenilir bilgi sunacağına inandıkları belirtilmiştir. Ergi ve Güleç (2019) ise BOBI FRS'ye yönelik muhasebe eğitimcileri ve uygulayıcılarına yönelik gerçekleştirdikleri anket çalışması sonucunda katılımcıların standartları olumlu karşılandığı, sürekli eğitim ihtiyacının olduğu, yeni hesap planını çalışmalarının gerekliliği gibi sonuçlar ortaya konmuştur.

KÜMİ FRS'ye yönelik gerçekleştirilen araştırmalar da benzer perspektifle BOBİ FRS, tam set ve VUK açısından karşılaştırmaların yapılması suretiyle ortaya konmuştur. Bu yaklaşımla Gökçen ve ark. (2019) KÜMİ FRS'yi BOBİ FRS ve tam set standartlarla temel konular bağlamında karşılaştırmışlardır. Gençoğlu (2020), KÜMİ FRS ile BOBİ FRS ve vergi uygulamalarını karşılaştırarak, KÜMİ FRS ile vergi yasalarındaki 'kar' hesaplanmasına yönelik ilkelerin benzerliğinden dolayı, ticari kâr ve mali kârın yakınlaşacağı ve standartların ticari muhasebe anlayışının yaygınlaşmasına katkı sunacağına yer vermiştir. Kıymetli Şen ve Özbirecikli (2020) KÜMİ FRS'yi BOBİ FRS, tam set standartlar ve VUK ile mukayese ederek standartların iş dünyasına sağlayabileceği faydaları incelemişlerdir. Araştırma sonucunda KÜMİ FRS'nin düşük maliyetli finansal bilgi sağlanmasına katkı sağlayacağı, MSUGT'deki eksikliklerin tamamlanmış olacağı gibi katkılarından bahsedilmiştir.

\section{Bulgular}

BOBİ FRS'yi kimlerin uygulayacağı mevzuatla belirli olmakla birlikte, KÜMİ FRS'nin kapsamının ne olacağı henüz kesinlik içermemekte ancak KGK’nin, 2013/34 Sayılı AB Direktifinde yer verilen ölçütleri benimsediği görülmektedir. İlgili direktife göre KÜMİ kriterleri ve yasal mevzuatta yer verilen BOBİ kriterleri aşağıdaki gibidir (www.kgk.gov.tr).

\begin{tabular}{|c|c|c|c|}
\hline \multicolumn{4}{|c|}{ Tablo 1: KÜMİ İşletme Ölçütleri } \\
\hline \multicolumn{4}{|c|}{ KÜMİ İşletme Ölçütleri (2013/34EU Directive) } \\
\hline İşletmeler & Aktif Büyüklük & Satış Hasılatı & Çalışan Sayısı \\
\hline Küçük İşletme & $€ 4.000 .000$ ve üstü & $€ 8.000 .000$ ve üstü & 50 ve üstü \\
\hline Mikro İşletme & $€ 350.000$ ve üstü & $€ 700.000$ ve üstü & 10 ve üstü \\
\hline
\end{tabular}

Tablo 2: BOBİ İşletme Ölçütleri

\begin{tabular}{|c|c|c|c|}
\hline \multicolumn{5}{|c|}{ BOBİ İşletme Ölçütleri } \\
\hline İşletmeler & Aktif Büyüklük & Satış Hasılatı & Çalışan Sayısı \\
\hline Büyük İşletme & $€ 75.000 .000$ ve üstü & $€ 150.000 .000$ ve üstü & 250 ve üstü \\
\hline Orta Büyüklükte İşletme & $€ 35.000 .000$ ve üstü & $€ 70.000 .000$ ve üstü & 175 ve üstü \\
\hline
\end{tabular}

KGK'nin verilerine göre, KAYİK kapsamında giren 1.580 işletme tam set standartları kullanmakta, 2.000 civarı büyük işletme ve 4.000 civarı orta büyüklükte işletme BOBİ FRS'leri uygulamakla yükümlü görülmektedir. KAYİK olmayıp bağımsız denetime tabi olan BOBİ kapsamındaki işletme sayısının 2018 KGK faaliyet raporuna göre 8.072 işletme olduğu görülmektedir (KGK 2018 Faaliyet Raporu, s. 73). 2018 yılında KAYİK dışında bağımsız denetim sözleşmesi imzalayan işletme sayısının, denetimin kapsamının genişletilmesine bağlı olarak yaklaşık iki kat (2017 yılında 4.588 KAYİK dışında işletme bağımsız denetim sözleşmesi imzalamıştır) arttığı görülmektedir (KGK 2017 Faaliyet Raporu, s. 70). Yine KGK'ya göre direktifte yer alan sınırlar dikkate alındığında KÜMİ FRS bağlamında 639.485 işletmenin kapsama gireceği düşünülmektedir. Bu yönüyle bilanço esasına göre defter tutan işletmelerin tamamında finansal raporlama standartlarının uygulanacağı öngörülmektedir (KÜMİ FRS Semineri, 2019, s. 4).

KOBİ IFRS, BOBİ FRS ve KÜMİ FRS genel hatları ile incelendiğinde temel niceliksel farkların şunlar olduğu görülmektedir. KOBİ IFRS 35 bölümden ve 239 sayfadan oluşmaktadır. BOBİ FRS 26 bölüm ve 238 sayfadır, KÜMİ FRS taslağı ise, 22 bölüm ve 104 sayfadan oluşmaktadır. Sayfa sayıları, yazım biçimi ve format farklılıklarından etkilenebilir özellikte olduğu için sayfa sayısından ziyade bölümler incelendiğinde en fazla bölüme KOBİ IFRS'nin sahip olduğu, KÜMİ FRS'nin daha az bölüm içerdiği görülmektedir. 
Üç standart setinde de ortak bir biçimde yer alan bölüm sayısının geçiş hükümleri ile birlikte 19 olduğu görülmektedir. Bazı bölümlerin diğer standart setinde iki ya da daha fazla bölümle ele alındığı, bazı bölümlere yer verilmediği ya da birleştirildiği görülmektedir. Standart bölümlerine ilişkin karşılaştırmaya ekler içerisinde yer alan Tablo-4'de yer verilmiştir. Bu üç standart setine ilişkin benzer bölümler arasındaki temel farklılıklara aşağıda yer verilmiştir.

\subsection{Kavramsal Çerçeve ve Finansal Tablolar}

Kavramsal çerçeve ve finansal tablolar KOBİ IFRS'de beş farklı (Bölüm 2-6) bölümde ele alınmış olmakla birlikte BOBİ FRS'de Bölüm 1 - Kavramsal Çerçeve ve Finansal Tablolar'da ele alınmıştır. Benzer bölüm KÜMİ FRS'de dört bölümde (Bölüm 1-4) ele alınmıştır. Söz konusu standartlar incelendiğinde kavramsal açıklamaların genel olarak benzer olduğu görülmektedir ve standartlara göre işletmelerce sunulması gereken finansal tablolar aşağıdaki gibidir (KOBİ IFRS 3.17; BOBİ FRS 1.3; KÜMİ FRS 2.3).

\begin{tabular}{|c|c|c|}
\hline \multicolumn{2}{|c|}{ Tablo 3: KOBİ IFRS, BOBİ FRS ve KÜMİ FRS Uyarınca Sunulması Gereken Finansal Tablolar } \\
\hline KOBİ IFRS & BOBİ FRS & KÜMİ FRS \\
\hline Finansal Durum Tablosu & Finansal Durum Tablosu & Finansal Durum Tablosu \\
\hline Gelir Tablosu ve Kapsamlı Gelir Tablosu & Kar veya Zarar Tablosu & Karar Tablosu \\
\hline Özkaynak Değişim Tablosu & Özkaynak Değişim Tablosu & - \\
\hline Nakit Aklş Tablosu & Nakit Aklş Tablosu & Dipnotlar \\
\hline $\begin{array}{c}\text { Onnemli muhasebe politikaları ve diğer } \\
\text { açılklaylcı bilgileri içeren dipnotlar }\end{array}$ & $\begin{array}{c}\text { Önemli muhasebe politikaları ve diğer } \\
\text { açılayıcı bilgileri içeren dipnotlar }\end{array}$ & \\
\hline
\end{tabular}

Standartlara göre düzenlenmesi gereken finansal tabloların KOBİ IFRS ve BOBİ FRS'de benzer olduğu görülmekte (KOBİ IFRS'de Kapsamlı Gelir Tablosu'na da yer verilmiştir), KÜMİ FRS'de Özkaynak Değişsim Tablosu ve Nakit Akış Tablosu'nun sunumu gerekli görülmemektedir. Ayrıca BOBİ FRS'de ara dönem raporlamaya ilişkin ayrı bir bölüme (Bölüm 24) yer verilmiş olmakla birlikte KÜMİ FRS'de böyle bir standart ya da ifade yer almamaktadır.

Finansal tablolarda sunulan bilgilerin özellikleri açısından KÜMİ FRS ile BOBİ FRS’nin uyumlu olduğu görülmektedir. $\mathrm{Bu}$ standartlarda faydalı finansal bilginin özellikleri; ihtiyaca uygunluk, gerçeğe uygun sunum, anlaşılabilirlik, karşılaştırılabilirlik, zamanında sunum olarak açıklanmıştır. KÜMİ FRS'de BOBİ FRS'den farklı olarak bu özellikler 'temel ve destekleyici' olarak sınıflandırılmıştır. KOBİ IFRS'de ise, bu iki standartta belirtilen özelliklere ek olarak önemlilik, güvenilirlik, özün önceliği, ihtiyatlılık, tam açıklama kavramlarına da yer verilmiştir (KOBİ IFRS 2.4-12; BOBİ FRS 1.7; KÜMİ FRS 2.8).

Genel olarak KÜMİ FRS'nin daha sade olduğu ve diğer standartlarca finansal tablolarda yer alması gerekli görülen bazı bölümlerin gerekli tutulmadığı görülmektedir. KÜMİ FRS'de bakiyesi olmayan kalemlere finansal durum tablosunda yer verilmeyebileceği hükmü yer almaktadır (KÜMİ FRS 3.3). Ayrıca KÜMİ FRS'de diğer standart setlerinden farklı olarak, sadece 3 temel ölçüm esasına (maliyet bedeli, gerçeğe uygun değer ve itibari değer) yer verilmiştir (KÜMİ FRS 1.12). KOBI IFRS'de örnek finansal tablolara yer verilmemiş olmakla birlikte BOBİ FRS ve KÜMİ FRS'de örnek finansal tablo şablonlarına yer verilmiştir.

\subsection{Dipnotlar}

Dipnotlar bölümüne ilişkin KÜMİ FRS ve BOBİ FRS'de yer alan hükümler genel olarak uyumludur. Bu standartlarda, dipnotların finansal tabloların anlaşılabilirliği ve karşılaştııılabilirliği üzerindeki etkisi dikkate alınarak sunum biçiminin belirlenmesi gerektiği vurgulanmıştır. Ayrıca bu standartlarda tüm işletmeler için yapılması gerekli olan açıklamalar ile işletmelerin özelliklerine göre (büyük işletme, küçük işletme, konsolide finansal tablo hazırlayan işletmeler) yapılması gerekli olan ek açıklamalar detaylı olarak açıklanmıştır. KOBİ IFRS'de ise, bu bölümdeki açıklamaların daha kısa olup sadece dipnotların genel yapısı ve hangi konulara dipnotlarda yer verilmesi gerektiği açıklanmıştır (KOBİ IFRS 8; BOBİ FRS 26; KÜMİ FRS 21). 


\subsection{Muhasebe Politikaları, Tahminler ve Hatalar}

Muhasebe politikalarl, tahminleri ve hatalar bölümünde yer alan düzenlemeler kapsam olarak KÜMİ FRS, BOBİ FRS ve KOBİ IFRS'de benzer şekilde ele alınmıştır. KÜMİ FRS ve KOBİ IFRS'de “hatalar” kavramı kullanılırken, BOBİ FRS'de “yanlışlıklar” kavramı kullanılmış olmakla bilirlikte iki kavramın aynı anlama sahip olduğu görülmektedir (KOBİ IFRS 10; BOBİ FRS 3; KÜMİ FRS 5).

\subsection{Finansal Araçlar ve Özkaynaklar}

Finansal varlıklar, finansal yükümlülükler (borçlar) ve işletmenin ihraç ettiği özkaynak araçlarına ilişkin muhasebe ilkeleri BOBİ FRS ve KÜMİ FRS'de finansal araçlar ve özkaynaklar bölümünde ele alınmıştır. KOBİ IFRS'de ise, finansal araçlar 'temel finansal araçlar', 'diğer finansal araçlar' ve 'borçlar ve özkaynaklar' bölümlerinde açıklanmıştır. Diğer taraftan KOBİ IFRS ve BOBİ FRS‘de 'iştiraklerdeki yatırımlar've 'müşterek girişimlerdeki yatırımlar' başl1kları altında ayrı bölümlerde ele alınan açıklamalara, KÜMİ FRS'de 'finansal araçlar ve özkaynaklar' bölümünde yer verilmiştir (KÜMİ FRS 10.2).

KOBİ IFRS'de finansal araçlar; gerçeğe uygun değer farkı kâr zarara yansıtılan finansal araçlar, değer düşüklüğü çıkarılmış maliyet bedeli üzerinden ölçülen finansal araçlar ve itfa edilmiş maliyet bedeli üzerinden ölçülen finansal araçlar şeklinde sınıflandırılmıştır (KOBİ IFRS 11.15-11.21-11.27). BOBİ FRS ve KÜMİ FRS'de ise finansal araçlar, alacaklar ve borçlar, borçlanma araçları, özkaynak araçlarındaki yatırımlar ve diğer finansal araçlar şeklinde sınıflandırılmıştır ( BOBİ FRS 9.7-9.22; KÜMİ FRS 10.9-10.19).

KOBİ IFRS'ye göre alacaklar ve borçlar ilk muhasebeleştirmede işlem fiyatından, sonraki dönemde itfa edilmiş maliyetleri üzerinden ölçülmektedir. Ancak, vadeli alım ve satıştan kaynaklanan alacaklar ve borçlar ilk muhasebeleştirmede net bugünkü değer üzerinden ölçülmektedir (KOBİ IFRS 11.13-14). BOBİ FRS'de alacakların ve borçların vadesi bir yıl veya daha kısa ise, itibari değer üzerinden, vadesi bir yıldan uzun ise itfa edilmiş değer üzerinden ölçüleceği belirtilmiştir (BOBİ FRS 9.8). KÜMİ FRS'de ise alacak ve borçların vadesine bakılmaksızın itibari değeri üzerinden ölçülür hükmüne yer verilmektedir. Ayrıca, KÜMİ FRS'de alacak ve borçların dönem sonunda reeskont işlemine tabi tutulacağı belirtilmiştir (KÜMİ FRS 10.10-11). BOBİ FRS ve KÜMİ FRS'de, makul bir gerekçeye dayanarak tahsili şüpheli hale gelen alacakların tahmin edilebileceği ve buna bağl1 olarak değer düşüklüğü karşılığg hesaplanacağ1 belirtilmiştir (BOBİ FRS 9.10; KÜMİ FRS 10.12). KOBİ IFRS'de yer verilen değer düşüklüğünün belirlenmesi ile ilgili düzenlemeler BOBİ FRS ve KÜMİ FRS ile uyumlu görülmekle birlikte KOBİ IFRS'de değer düşüklüğüne dair ancak tarafsız bir kanıt olması durumunda, değer düşüklüğü karşılığının hesaplanacağı açıklanmıştır (KOBİ IFRS 11.21).

KOBI IFRS'de borçlanma araçlarının ilk muhasebeleştirilmesinde gerçeğe uygun değer üzerinden ölçüleceği açıklamıştır. BOBİ FRS'de borçlanma araçlarının ilk muhasebeleştirilmesinde, aracılara, danışmanlara ve düzenleyici kurumlara ödenen komisyon ve ücretler gibi işlem maliyetleri alış bedeline ilave edilirken, KÜMİ FRS'de işlem maliyetleri gider olarak kâr ve zarara yansıtılmaktadır (BOBİ FRS 9.12; KÜMİ FRS 10.14). KOBİ IFRS'ye göre borçların ihraç edilmesiyle ilgili işlem maliyetleri ise ilk muhasebeleştirmede ölçülen değerden çıkartılmaktadır (Bahadır, 2012, s. 50). Borçlanma araçlarının sonraki dönemlerde ölçümünde KOBİ IFRS ve BOBİ FRS'de itfa edilmiş maliyet ölçüsü belirtilmiştir. KÜMİ FRS'de ise, borçlanma araçlarının sonraki dönemlerde ölçümünde, işlem fiyatına, raporlama dönemi sonunda tahakkuk eden faiz gelir veya giderleri eklenmekte, dönem sonuna kadar gerçekleşmiş tüm anapara geri ödemeleri ve faiz ödeme veya tahsilatları çıkartılmakta ve eğer varsa değer düşüklüğü zararları düşüldükten sonraki değeri dikkate alınmaktadır (KOBİ IFRS 11.15; BOBİ FRS 9.11; KÜMİ FRS 10.16).

BOBİ FRS'de borsada işlem gören özkaynak araçları, ilk muhasebeleştirmede işlem fiyatından ölçülmekte ve işlem maliyetleri dönem gideri olarak muhasebeleştirilmektedir. Bu özkaynak araçları dönem sonunda gerçeğe uygun değerleri üzerinden ölçülür ve ortaya çıkan değer farkları kâr veya zarara yansıtılır (BOBİ FRS, 9.20). KÜMİ FRS'de 'borsada işlem gören özkaynak araçları' konusu genişletilerek, bu bölüme 'müştereken kontrol edilen işletme veya iştirak yatırımlarındaki paylar' konusu eklenmiştir. Burada belirtilen özkaynak araçların ilk ölçümü gerçeğe uygun değer (işlem fiyatı) üzerinden 
ölçüleceği ve işlem maliyetlerinin kâr veya zarara yansıtılacağı belirtilmiştir. Özkaynağa dayalı finansal araçların bir sonraki ölçümünün BOBİ FRS'de belirtildiği gibi gerçeğe uygun değerleri ile yapılacağı ve ortaya çıkan değer farklarının kar veya zarara yansıtılacağı açıklanmıştır (KÜMİ FRS 10.17; BOBİ FRS 9.20). KOBİ IFRS'de ise özkaynak araçları, gerçeğe uygun değerleri güvenilir bir şekilde ölçülebiliyorsa gerçeğe uygun değeri ile ölçülmektedir ve değerleme farkı kâr veya zarara aktarılmaktadır (KOBİ IFRS 11.27).

BOBİ FRS ve KÜMİ FRS'de borsada işlem görmeyen öz kaynak araçları ilk muhasebeleştirmede işlem fiyatları ve işlem maliyetlerinin toplamında oluşan maliyet bedeli ile ölçüleceği, sonraki ölçümde maliyet bedelinden varsa değer düşüklüğü zararı düşülerek finansal tablolarda yer alacağı belirtilmiştir (BOBİ FRS 9.21; KÜMİ FRS 10.18). KOBİ IFRS'de ise, özkaynak araçların aktif bir piyasası olmaması durumunda en son tarihteki defter değerinin yeni maliyetini oluşturacağı açıklanmış ve bu durumda maliyet değerinden varsa değer düşüklüğü zararı düşüleceği hükmüne yer verilmiştir (KOBİ IFRS 11.32).

Üç standart setinde de varlığa dayalı menkul kıymetler ve türev finansal araçların ilk kayda almada ve sonraki dönemlerde, gerçeğe uygun değeri ile ölçüleceği ve ölçüm farklarının kâr veya zarara yansıtılacağı belirtilmiştir (KOBİ IFRS 12.7-12.8; BOBİ FRS 9.26; KÜMİ FRS 10.19).

\subsection{Stoklar}

KOBİ IFRS ve BOBİ FRS'de stokların vadeli alımından kaynaklanan finansman giderlerinin ayrıştırılması konusunun benzer şekilde ele alındığı görülmektedir. Ancak KOBİ IFRS'de stok alımlarının vadesine bakılmaksızın vade farkı ayrıştırılırken, BOBİ FRS'de bir yıldan uzun vadeli stok alımlarında vade farkı ayrıştırılmaktadır. KÜMİ FRS'de ise, vadeli stok alımlarında vade farkı ayrıştırma işleminin yapılmayacağı belirtilmiştir (KOBİ IFRS 13.7; BOBİ FRS 6.8; KÜMİ FRS 8.8).

BOBİ FRS ile KOBİ IFRS'de stokların ölçümü ile ilgili düzenlemeler uyumludur. Bu standartlara göre, stoklar, maliyet bedeli ile net gerçekleşebilir değerden düşük olanı üzerinden ölçülmektedir. KÜMİ FRS'de ise, stokların maliyet değeri ile ölçüleceği belirtilmiştir (KOBİ IFRS 13.4; BOBİ FRS 6.4; KÜMİ FRS 8.4).

KOBİ IFRS'de borçlanma maliyetlerinin tamamının gider olarak kaydedileceği hükmüne yer verilirken (KOBİ IFRS 25.2), BOBİ FRS'de borçlanma maliyetlerinin oluştukları dönemde kâr veya zarara yansıtılacağı, ancak üretilmesi bir yıldan uzun süren stoklar için katlanılan borçlanma maliyetlerinin satışa hazır hale geldiği tarihe kadar stok maliyetine dâhil edileceği belirtilmiştir (BOBİ FRS 6.9). KÜMİ FRS'de ise, stoklara ilişkin borçlanma maliyetlerinin oluştukları dönemde kâr veya zarar yansıtılacağına yer verilmiştir (KÜMİ FRS 8.9).

BOBİ FRS ve KÜMİ FRS dönüştürme maliyetlerinin belirlenmesinde benzer şekilde tam maliyet yöntemini benimsemiştir. Bu standartlarda dönüştürme maliyetlerinin belirlenmesinde normal maliyet yönteminin de kullanılabileceği belirtilmiştir (BOBİ FRS 6.12-13; KÜMİ FRS 8.11-12). KOBİ IFRS ise, dönüştürme maliyetlerinin belirlenmesinde normal maliyet yöntemini benimsemiştir (KOBİ IFRS 13.8).

BOBİ FRS ve KÜMİ FRS'de mamul maliyetlerinin ölçüm teknikleri ile ilgili açıklamalar uyumludur. Bu standartlarda, mamul maliyetlerinin, üretim giderlerinin gerçekleşmiş tutarlarına göre fiili maliyet yöntemi kullanılarak belirleneceği açıklanmıştır (BOBİ FRS 6.19; KÜMİ FRS 8.16). KOBİ IFRS'de ise, stokların maliyetinin ölçümüne yönelik standart maliyet yöntemi, perakende yöntemi veya en güncel alış fiyatı gibi teknikler önerilmiştir (KOBİ IFRS 13.16).

KOBİ IFRS ve BOBİ FRS'de stok kaleminin değer düşüklüğü stok kaleminin net gerçekleşebilir değeri dikkate alınarak belirlenmektedir (KOBİ IFRS 13.19; BOBİ FRS 6.4). KÜMİ FRS'de ise, farklı bir uygulamaya yer verilerek dönem sonunda, stokların tahmini satış fiyatı maliyet bedelinden $\% 10$ veya daha fazla düşükse, söz konusu değer düşüklüğünün finansal tablolara yansıtılacağı belirtilmiştir (KÜMİ FRS 8.19). KOBİ IFRS ve BOBİ FRS'de ortak ürünlerin ve yan ürünlerin maliyetlerinin belirlenmesine yönelik açıklamalara yer verilirken, KÜMİ FRS'de bu konuda açıklamaya yer verilmemiştir (BOBİ FRS 6.16; KOBİ IFRS 13.10). 


\subsection{Maddi Duran Varlıklar}

Üç standart setine göre maddi duran varlıkların ilk kayda alınmasında maliyet bedeli ile ölçüme yer verilmiştir. Maddi duran varlıkların sonraki ölçümü ile ilgili düzenlemeler BOBİ FRS ve KÜMİ FRS'de uyumlu olarak sonraki ölçümlerde maliyet yöntemi veya yeniden değerleme yönteminin kullanılabileceği belirtilmiştir (BOBİ FRS 12.15; KÜMİ FRS 11.15). KOBİ IFRS'de ise, maddi duran varlığın sonraki ölçümünde sadece maliyet yöntemi belirtilmiştir (KOBİ IFRS 17.15). Üç standart setinde amortisman yöntemleri ve maddi duran varlığın değer düşüklüğünün tespitine yönelik açıklamalar uyumludur. Bu standartlarda amortisman uygulaması için doğrusal yöntem, azalan bakiyeler yöntemi ve üretim miktarı yöntemleri önerilmiş ve değer düşüklüğü testinin her hesap dönemi sonunda yapılması gerektiği açıklanmıştır.

KOBİ IFRS ve BOBİ FRS'de yatırım amaçlı gayrimenkuller ile ilgili düzenlemeler ayrı bölümde açıklanmıştır. KÜMİ FRS'de ise, işletmelerin isteğe bağlı olarak BOBİ FRS'de yer alan 'yatırım amaçlı gayrimenkuller' hükümlerini uygulayabilecekleri belirtilmiştir (KÜMİ FRS 11.4).

\subsection{Maddi Olmayan Duran Varlıklar}

Söz konusu standartlara göre maddi olmayan duran varlıklar ilk kayda almada maliyet bedeli ile ölçülür ve sonraki ölçümde kullanılacak yöntemle ilgili açıklamalar da uyumludur. Standartlara göre, maddi olmayan duran varlıklar, ilk kayda alındıktan sonra birikmiş itfa payları ve birikmiş değer düşüklüğü zararları düşülmek suretiyle maliyeti üzerinden ölçülür. KOBİ IFRS'de maddi olmayan duran varlıkların faydalı ömrü tespit edilemiyorsa, faydalı ömrü 10 yıl olarak kabul edileceği belirtilmiştir. BOBİ FRS ve KÜMİ FRS'de ise, faydalı ömür için belirlenen sürenin 5 y1ldan az 10 yıldan çok olmayacağ açıklanmıştır (BOBİ FRS 14.33; KÜMİ FRS 12.25; KOBİ IFRS 18.20). Yine bu üç standart setinde amortisman yöntemleri ve maddi olmayan duran varlığın değer düşüklüğünün tespitine yönelik açıklamalar uyumludur

İşletme içinde yaratılan maddi olmayan duran varlıklara ilişkin araştırma ve geliştirme evrelerinde oluşan giderlerin nasıl raporlanacağına ilişkin düzenlemeler farklılık göstermektedir. BOBİ FRS'de araştırma evresinde yapılan harcamaların aktifleştirilemeyeceği, doğrudan gider yazılacağı, ama geliştirme evresinde yapılan harcamaların aktifleştirilebileceği belirtilmiş̧ir. KOBİ IFRS'de hem araştırma hem de geliştirme evrelerindeki harcamaların gider yazılacağına yer verilmiştir. KÜMİ FRS'de ise, araştırma ve geliştirme ayrımı yapılmadan işletmede oluşturulan unsurla ilgili harcamaların gider yazılacağı belirtilmiştir (BOBİ FRS 14.16; KÜMİ FRS 12.6; KOBİ IFRS 18.14).

\section{8. İşletme Birleşmeleri}

KOBİ IFRS'de ortak kontrole tabi işletmelerin veya teşebbüslerin birleşmelerinde, bir iş ortaklığ 1 kurulmasında ve işletme tanımına uymayan varlıkların alımında 'iş birleşmeleri' bölümünde yer alan hükümlerin uygulanmayacağı belirtilmiştir. BOBİ FRS'de, KOBİ IFRS'de yapılan açıklamaya ek olarak konsolide finansal tablo hazırlamayan şirketlerin bağlı ortaklık edinimlerinde 'iş birleşmeleri' bölümündeki hükümleri uygulamayacağı açıklanmıştır. KÜMİ FRS'de ise, iştirak edinimlerine, müştereken kontrol edilen işletmenin oluşumuna ve bağlı ortaklık edinimlerine ilişkin ilgili bölümündeki hükümlerin uygulanmayacağı belirtilmiştir. Bu açıklamalardan, BOBİ FRS ve KÜMİ FRS'de bu konunun kapsamının daraltıldığı söylenebilir (KOBİ IFRS 19.2; BOBİ FRS 21.5; KÜMİ FRS 19.4).

KÜMİ FRS'de işletme birleşmeleri konusunda yapılan açıklamalar diğer standartlara göre daha kısa olmasına rağmen, BOBİ FRS ile uyumludur. Çünkü KÜMİ FRS'de işletme birleşmelerinin finansal tablolara alınmasında uygulanacak muhasebe ilkeleri için BOBİ FRS'ye atıfta bulunulmuştur (KÜMİ FRS 19.5).

İşletme birleşmelerinde ortaya çıkan şerefiyenin itfası ile ilgili hükümler genel olarak uyumludur. Ancak BOBİ FRS ve KÜMİ FRS'de şerefiyede değer düşüklüğü testi uygulanmazken, KOBİ IFRS'de değer düşüklüğü testine yer verilmiştir (KOBİ IFRS 19.23; BOBİ FRS 21.27; KÜMİ FRS 16.11). 


\subsection{Kiralamalar}

Kiralama işlemlerinde finansal kiralama ve faaliyet kiralamalarına yer verilmiştir. Genel olarak standartlarda faaliyet ve finansal kiralamalarının finansal tablolara alınmasında belirtilen hükümler uyumludur. $\mathrm{Bu}$ standartlarda finansal kiralamada kira ödemeleri ilk kayda alındıktan sonra finansman giderleri ve borç ve anapara ödemesi olarak ayrıştırılacağ 1 belirtilmiş̧ir. Finansman giderlerinin ise, kalan borç tutarına sabit bir faiz oranı uygulanmasını sağlayacak şekilde kiralama süresi boyunca her bir döneme dağıtılacağı açıklanmıştır (KOBİ IFRS 20.15; BOBİ FRS 15.17; KÜMİ FRS 13.16).

Faaliyet kiralamasında kiracıların ve kiraya verenlerin uygulayacağı muhasebe ilkeleri de genel olarak uyumludur. $\mathrm{Bu}$ standartlara göre, kiraya veren kira ödemelerini doğrusal olarak kiralama süresi boyunca gider, kiraya veren kira ödemelerini doğrusal olarak kiralama süresi boyunca gelir kayıt edecektir (KOBİ IFRS 20.25; BOBİ FRS 15.28; KÜMİ FRS 13.18). Satılan varlığın geri kiralanması ile ilgili hükümler KOBİ FRS ve BOBİ FRS'de yer alırken, KÜMİ FRS'de yer almamaktadır (KOBİ IFRS 20.32; BOBİ FRS 15.31).

\subsection{Karşılıklar, Koşullu Borçlar ve Varlıklar}

Üç standart setinde de karşılık tutarının beklenen harcama tutarı veya bugünkü değeri üzerinden ölçüleceği belirtilmiştir. $\mathrm{Bu}$ standartlarda, karşılık tutarının, yükümlülüğün yerine getirilmesi için yapılması gereken harcamalara yönelik en gerçekçi tahmin üzerinden ölçülür ifadesi kullanılmıştır (KOBİ IFRS 21.7; BOBİ FRS 19.13; KÜMİ FRS 17.9).

KOBİ IFRS'de kıdem tazminatı ile ilgili açıklamalar 'çalışanlara sağlanan faydalar' bölümünde açıklanırken, BOBİ FRS ve KÜMİ FRS'de 'karşıllklar, koşullu borçlar ve varlıklar' bölümünde açıklanmıştır. BOBİ FRS ve KÜMİ FRS'de kıdem tazminatı karşılıklarının cari dönemde kıdem tazminatı yükümlülük artışları dikkate alınarak hesaplanacağı belirtilirmiş̧ir. KOBİ IFRS'de ise, kıdem tazminatı karşılığının iskonto edilmiş bugünkü değer üzerinden ölçüleceği belirtilmiştir (KOBİ IFRS 21.37; BOBİ FRS 19.17; KÜMİ FRS 17.16).

Üç standartta şarta bağlı (koşullu) yükümlülükler ile şarta bağlı (koşullu) varlıkların raporlama ilkeleri uyumludur. Bu standartlarda şarta bağlı yükümlülüklerin ve varlıkların finansal tablolarda gösterilmeyeceği belirtilmiştir. Standartlara göre, şarta bağlı yükümlükle ilgili kaynak çıkışının olasıllığı düşük değil ise, şarta bağlı varlıkların ekonomik fayda girişinin olma ihtimali varsa dipnotlarda açıklanacağı belirtilmiştir (KOBİ IFRS 21.12; BOBİ FRS 19.20; KÜMİ FRS 17.21).

\subsection{Hâsılat}

Hasılatın kayda alınmasında kullanılan ölçütlerle ilgili açıklamaların üç standart setinde uyumlu olduğu görülmektedir. Bu standartlarda hasılatın kaydedilmesinde 'ekonomik faydanın işletmeye girmesi' ifadesi ön plana çıkmaktadır. Ancak bu standartlarda hasılatın ölçümü ile ilgili açıklamalarda farklılıklar vardır. KOBİ IFRS'ye göre hasılat, içerdiği faiz tutarı ayrıştırılarak muhasebeleştirilir. Hasılat gelecek dönemde tahsil edildiği durumda, iskonto edilerek gerçeğe uygun değeri üzerinden muhasebeleştirilir (KOBİ IFRS, 23.5). BOBİ FRS'de ise, hasılat bedelinden faiz tutarını ayrıştırma işlemi vadeye bağlanmıştır. BOBİ FRS'de hasılat bedelinin bir yıl veya daha kısa sürede tahsil edilmesi öngörülmesi durumunda hasılat, vade farkı ayrıştırılma işlemi yapılmaksızın doğrudan tahsil edilen veya edilmesi beklenen bedel üzerinden ölçüleceği belirtilmiştir. Bu bedel, bir yıldan daha uzun bir vadede tahsil edilmesinin öngörülmesi durumunda hasılat, işlemdeki vade farkı ayrıştırma işlemi yapılarak mal veya hizmetin peşin bedeli üzerinden ölçüleceği açıklanmıştır. KÜMİ FRS'de ise, hasılat taraflar arasında yapılan anlaşma kapsamında, satış iskontoları düşüldükten sonra, vade farkı ayrıştırılmaksızın doğrudan tahsil edilen veya edilmesi beklenen bedel üzerinden ölçüleceği belirtilmiştir (BOBİ FRS 5.9; KÜMİ FRS 7.5).

KOBİ IFRS, BOBİ FRS ve KÜMİ FRS'de hizmete ilişkin hasılat tutarının belirlenmesi ile ilgili açıklamalar uyumludur. Bu standartlarda hizmet sunumuna ilişkin hasılat tutarının belirlenmesinde işlemin raporlama dönemi sonu itibarıyla tamamlanma yüzdesi yöntemi kullanılarak kayda alınacağı belirtilmiştir (KOBİ IFRS 23.14; BOBİ FRS 5.18; KÜMİ FRS 7.14). 


\subsection{Devlet Teşvikleri}

Üç standart setinde de devlet teşviklerinin gerçeğe uygun değer üzerinden ölçüleceği belirtilmiştir (KOBİ IFRS 24.5; BOBI FRS 16.8; KÜMİ FRS 14.7). BOBİ FRS'de piyasa faiz oranından düşük bir faiz oranıyla devletten alınan kredi devlet teşviki olarak kabul edilmekte ve bu tür kredinin muhasebeleştirme ilkeleri açıklanmaktadır. Ancak, KOBİ IFRS ve KÜMİ FRS taslağında bu konuda açıklama yer almamaktadır (BOBİ FRS 16.9).

\subsection{Borçlanma Maliyetleri}

KOBİ IFRS ve KÜMİ FRS'de, borçlanma maliyetlerinin oluştuğu dönemde kâr veya zarar tablosunda ilgili kaleme yansıtılacağı belirtilmiştir. BOBİ FRS'de ise, daha farklı bir yaklaşım izlenmiştir. Standarda göre, üretilmesi, inşası veya oluşturulması normal şartlar altında bir yıldan daha uzun süren stokların, maddi duran varlıkların, yatırım amaçlı gayrimenkullerin ve maddi olmayan duran varlıkların elde edilmesiyle doğrudan ilişkili olan borçlanma maliyetleri satışa veya kullanıma hazır hale getirildiği tarihe kadar, varlığın maliyetine dâhil edileceği belirtilmiştir. Diğer tüm borçlanma maliyetlerinin ise, oluştukları dönemde kâr veya zarar tablosunda ilgili kaleme yansıtılacağı ifade edilmiş̧ir (KOBİ IFRS 25,2; BOBİ FRS 17.2; KÜMİ FRS 15.3).

\subsection{Varlıklarda Değer Düşüklüğü}

KOBİ IFRS ve BOBİ FRS'de değer düşüklüğünün tespitine ilişkin hükümler genel olarak uyumludur. Bu standartlarda varlığın değer düşüklüğü geri kazanılabilir tutar üzerinden belirlenmektedir. Varlığın defter değerinin geri kazanılabilir tutarından büyük olması durumunda değer düşüklüğü zararı oluşmaktadır. KÜMİ FRS'de ise, varlığın defter değeri ile satış maliyetleri düşülmüş gerçeğe uygun değeri karşılaştırılarak değer düşüklüğü test edilmektedir (KOBİ IFRS 27.5; BOBİ FRS 18.3; KÜMİ FRS 16.3). Şerefiyenin değer düşüklüğü testi ile ilgili açılamalar ise sadece KOBİ IFRS'de yer almaktadır. BOBİ FRS ve KÜMİ FRS'de bu konuda açıklama yapılmamıştır (KOBİ FRS 27.25).

KOBİ IFRS ve BOBİ FRS'de değer düşüklüğünün belirlenmesinde herhangi bir sayısal ölçüt açıklanmamıştır. Ancak KÜMİ FRS'de varlığın satış maliyetleri düşülmüş gerçeğe uygun değerinin, defter değerinden $\% 10$ veya daha fazla düşük olması durumunda varlıklara ilişkin değer düşüklüğü zararlarının kâr veya zarara yansıtılması gerektiği ifade edilmiştir (KÜMİ FRS 16.8).

\subsection{Gelir Üzerinden Alınan Vergiler}

KOBİ IFRS'de gelir vergileri olarak ifade edilen bölüm, diğer standart setlerinde gelir üzerinden alınan vergiler şeklinde ele alınmıştır. BOBİ FRS'de vergiye esas değer KOBİ IFRS'nin aksine varlık ve yükümlülükler için ayrı ayrı ele alınmıştır (KOBİ IFRS 23.14-17). Benzer durum geçici farklar için de söz konusudur, BOBİ FRS'de geçici farklar detaylı olarak tanımlanarak vergiye tabi ve indirilebilir geçici farklar olarak gruplandırılmıştır (BOBİ FRS 23.18-20). Diğer bir fark, ertelenmiş verginin ölçümüne yöneliktir, BOBİ FRS'de amortismana tabi olmayan maddi duran varlıklar ve faydası işletme tarafından tüketilmeyecek yatırım amaçlı gayrimenkullere ilişkin ertelenmiş vergide, söz konusu varlıkların satışında dikkate alınacak vergi oranın kullanılması gerektiğine yer verilmiştir (BOBİ FRS 23.36).

Genel olarak BOBİ FRS ve KOBİ IFRS'nin benzer yaklaşımla ele alındığı, BOBİ FRS'nin daha fazla madde içerdiği ve çeşitli örneklere yer verdiği görülmektedir. KÜMİ FRS'de gelir vergileri kapsamında ertelenmiş vergi varlığı ve yükümlüğüne yer verilmesi gerekli görülmemiş (KÜMİ FRS 20.2) olmakla birlikte BOBİ FRS'de sadece büyük işletmelerin ertelenmiş vergi kalemine yer vermesi zorunlu tutulmuştur (BOBİ FRS 23.3).

\subsection{Yabancı Para Çevrim İşlemleri}

Genel olarak yabancı para çevrim işlemlerinin üç standart setinde de benzer olduğu görülmektedir. KOBİ IFRS'de geçerli para birimi olarak ifade edilen kavram BOBİ FRS ve KÜMİ FRS'de ăğrlıkla kullanılan para birimi şeklinde ele alınmıştır (KOBİ IFRS 30.2; BOBİ FRS 20.2; KÜMİ FRS 18.2). KOBİ IFRS'de çevrimde kullanılacak kurun "geçerli kur" olması 
gerektiği yer almakla birlikte, BOBİ FRS'de "spot kur", KÜMİ FRS'de "TCMB kurunun" dikkate alınması gerektiğine yer verilmiştir (KOBİ IFRS 30.7; BOBİ FRS 20.8; KÜMİ FRS 18.7).

Ayrıca üç standart setinde parasal olmayan kalemlerden kaynaklanan kur farkı kazanç ya da kayıplarının kar zarar tablosu kalemi kullanılarak (KOBİ IFRS'de diğer kapsamlı gelir içerisinde) işleme alınacağına yer verilirken BOBİ FRS'de bunun dışında maddi duran varlıklarla ilgili yeniden değerleme farklarının 'Yeniden Değerleme Yedeğinde' gösterilmesi gerektiğine yer verilmiştir (KOBİ IFRS 30.11; BOBİ FRS 20.17; KÜMİ FRS 18.13). Ayrıca BOBİ FRS'de bölüm kapsamında yabancı para cinsinden avans bedellerine yer verilmemiş olmakla birlikte bu husus KÜMİ FRS'de açıklanmıştır (KÜMİ FRS 18.20).

KOBİ IFRS'de BOBİ FRS ve KÜMİ FRS'de ki gibi parasal olan ve parasal olmayan kalemlerin neler olduğu açıklanmamıştır. Ayrıca BOBİ FRS, enflasyonist ortamda Bölüm 25'e göre ilgili düzeltmelerin yapılması gerektiğini içermektedir (BOBI FRS 20.21). Bağlı ortaklıklar, iştirakler ve müşterek girişimlere ilişkin yabancı para cinsi işlemlerinin ne şekilde ele alınacağ1 KÜMİ FRS taslağında boş bırakılmış olmakla birlikte (KÜMİ FRS 18.17), BOBİ FRS'de bu bölüm diğer iki standart setine göre detaylı açıklamalarla ele alınmıştır (BOBİ FRS 20.24).

\subsection{Raporlama Döneminden Sonraki Olaylar}

Genel olarak raporlama döneminden sonraki olaylara ilişkin hükümlerin üç standart setinde de çok benzer olduğu görülmektedir. Bununla birlikte KOBİ IFRS'de düzeltme gerektirmemekle birlikte dipnotlarda açılanması gereken hususlar örneklendirilmiştir (KOBİ IFRS 32.9-11). KÜMİ FRS'de de BOBİ FRS'ye göre bazı finansal tabloların sunulmasının gerekmemesinden dolayı örnek ve açıklamalarda farklar bulunmaktadır (KÜMİ FRS 6.7).

KOBİ IFSR Bölüm 32'de yer verilmemekle birlikte BOBİ FRS ve KÜMİ FRS'de raporlama tarihinden sonra, işletmenin sürekliliği varsayımın ortadan kalktığı durumlara işaret edilerek böyle bir durumun var olması durumunda yapılması gereken açıklamalar ele alınmıştır (KÜMİ FRS 6.10; BOBİ FRS 4.10).

\subsection{Tarımsal Faaliyetler}

Tarımsal faaliyetler KOBİ IFRS'de Bölüm 34 - Özellikli Faaliyetler içerisinde ele alınmıştır ve tarımsal faaliyetler dışında, imtiyazlı hizmet ve maden çıkarma faaliyetleri de standart kapsamında ele alınmıştır. Maden çıkarma faaliyetlerine ilişkin KÜMİ FRS'de herhangi bir bölüm bulunmazken, bu konu BOBİ FRS'de Bölüm 8 - Maden Kaynaklarının Aranması ve Değerlendirilmesi' bölümünde açıklanmıştır.

BOBİ FRS ve KÜMİ FRS'de tarımsal faaliyet, canlı varlık, tarımsal ürün, biyolojik dönüşüm ve hasat kavramları açıklanırken KOBİ IFRS'de böyle bir açıklamaya yer verilmemiştir. Yine BOBİ FRS ve KÜMİ FRS setinde canlı varlıklar, tarımsal ürünler ve işlenmiş ürünlere iliş̧in örneklere yer verilmiştir (BOBİ FRS, 7.3; KÜMİ FRS 9.4). Genel olarak tarımsal varlıkların muhasebeleştirilmesine ilişkin üç standart setinde benzerlikler olmasının yanında aşağıdaki farkların olduğu tespit edilmiştir.

KOBİ IFRS'de değeri aşırı çaba ve maliyete katlanmadan belirlenebilen canlı varlıklar için "gerçeğe uygun değer yönteminin" kullanılması zorunlu tutulurken (KOBİ IFRS 34.2), diğer iki standart setinde "maliyet yönteminin" de kullanılabileceği hükmü bulunmaktadır (BOBİ FRS, 7.5 - KÜMİ FRS 9.5). Ancak BOBİ FRS'de gerçeğe uygun değer yöntemi uygulandıktan sonra aynı canlı varlık için maliyet yöntemine geçiş yapılamayacağına yer verilirken (BOBİ FRS 7.6) KÜMİ FRS'de böyle bir hüküm yer almamaktadır. BOBİ FRS'de canlı varlıkların ve tarımsal ürünlerin ölçüm ve muhasebeleştirilmesi ayrı ayrı ele alınmış olmakla birlikte KOBİ IFRS ve KÜMİ FRS'de böyle bir ayrıma yer verilmeden ilgili hükümler tarımsal faaliyetler başlığı altında incelenmiştir.

\section{Tartışma ve Sonuç}

Ülkemizde ulusal muhasebe standartlarının uluslararası muhasebe standartları ile uyumlu olması amacıyla bir dizi düzenlemeler yapılmıştır. Bu düzenlemelerden en önemlisi 6102 sayılı TTK'da yer alan hükümlerdir. Bu kanun ile birlikte 
defter tutma yükümlülüğü olan gerçek ve tüzel kişi tacirlerin finansal tablolarını KGK tarafından yayınlanan TFRS'lere uygun hazırlaması zorunlu hale gelmiştir. Halka açık şirketler dışında kalan şirketler için KOBI IFRS yayınlanmışıı. KOBI IFRS tam setlerin kapsamına girmeyen işletmelerin tamamını tek bir ölçekte ele alarak söz konusu işletmelerin tamamı için tek bir standart seti ortaya koymuştur. Ülkemizde de 2013 yılından itibaren uygulanması beklenen bu standart seti, uygulanamadan yürürlükten kaldırılmıştır. İlerleyen süreçte tam set standartları uygulamayan ancak bağımsız denetime tabi olan işletmelerin dikkate aldığı MSUGT yeterli görülmemiş ve yeni bir standart setinin hazırlanması gündeme gelmiştir. $\mathrm{Bu}$ amaçla Avrupa'daki gelişmeler dikkate alınarak BOBİ FRS hazırlanmış ve uygulamaya girmiştir. Ayrıca 2021 yılından itibaren de KÜMI FRS standartlarının uygulamaya girmesi beklenmektedir. Bu yeni standart setlerinde işletmeler büyüklüklerine göre dört farklı kategoride ele alınmış ve standartlar işletmelerin ihtiyaçları dikkate alınarak hazırlanmıştır.

$\mathrm{Bu}$ araştırmada söz konusu üç standart seti incelenmiş ve aralarındaki farkları ele alınmıştır. KOBİ IFRS'ye göre bazı standartlar arasında benzerlikler yanında önemli farklar söz konusu olmakla birlikte BOBİ FRS ve KÜMİ FRS'nin daha benzer olduğu görülmüştür. Bununla birlikte KÜMİ FRS'de genellikle muhasebeleştirilmesi kolay olan yöntemler ele alınmış ve KÜMİ'lerin ihtiyaç duymayacağı hususlara yer verilmeyerek sadelik ve anlaşılabilirlik sağlanmıştır. Gerek KOBİ IFRS gerekse BOBİ FRS ve KÜMİ FRS tam set IFRS'lerin genel yapısına uygun standart setleridir. Eğer standartların, kapsam ve uygulama zorluğu bakımından sıralaması yapılacak olursa, IFRS, KOBİ IFRS, BOBİ FRS ve KÜMİ FRS şeklinde bir sıralama doğru olacaktır.

Genel olarak söz konusu standart setlerinin 'muhasebenin vergiden ziyade bilgi ihtiyacına hizmet etmesi' ilkesine katk1 sunacağı düşünülmektedir. Özellikle KÜMİ FRS’nin de uygulamaya girmesi ile henüz kapsam belirli olmamakla birlikte bilanço esasına göre muhasebe uygulamalarını yürüten tüm işletmelerde uluslararası standartların uygulanacağı ifade edilebilir. Ancak bununla birlikte bağımsız denetime tabi olmayan işletmeler için vergi incelemeleri dışında finansal tabloların denetimi söz konusu olmadığı için özellikle KÜMİ FRS'nin uygulama durumuna ilişkin kontrolün nasıl sağlanacağı soru işaretidir. Diğer bir yandan ayrı bir muhasebe birimi olmayan küçük ve mikro büyüklükteki işletmelerden dolayı meslek mensubu SMMM'ler de bu süreçten etkilenecektir. Bu yönüyle meslek mensupları içinde bir değişim süreci söz konusu olacaktır.

Ayrıca ülkemizde hem cumhuriyet öncesinde hem de cumhuriyet döneminde muhasebe konusunda batının gerisinde kalındığı ifade edilmektedir. Özellikle ABD ve Avrupa'da 19. yüzyılın sonlarından itibaren muhasebe alanındaki gelişmelerin benzerleri ülkemizde çok daha geç görülmüştür. 20. yüzyılın sonlarına doğru başlayan muhasebe konusundaki gelişmeler 21. yüzyılın başında uluslararası standartlara uyum, bağımsız denetim zorunluluğu ve kapsamının genişletilmesi gibi gelişmelerle önemli bir seviyeye gelmiştir. Her ne kadar geçmişte muhasebe konusunda batının gerisinde kalındığı ifade edilse de yakın zamanda yaşanan gelişmeler ve son olarak BOBİ FRS ve uygulamaya girmesi planlanan KÜMİ FRS süreci ile ülkemizin, muhasebe konusunda çağdaş uygulamaları eş zamanlı uygulayabilen bir noktaya geldiği düşünülmektedir.

Hakem Değerlendirmesi: Dıș bağımsız.

Çıkar Çatışması: Yazarlar çıkar çatışması bildirmemiştir

Finansal Destek: Yazarlar bu çalışma için finansal destek almadığını beyan etmiştir.

Peer-review: Externally peer-reviewed.

Conflict of Interest: The authors have no conflict of interest to declare.

Grant Support: The authors declared that this study has received no financial support.

\section{Kaynaklar}

2013/34/EU Directive, (2013, 26 Haziran). https:/eur-lex.europa.eu/legal-content/EN/TXT/PDF/?uri=CELEX:32013L0034\&from=EN

Ağca, A. ve Aktaş, R. (2007). Uluslararası muhasebe / finansal raporlama standartları İMKB'de yer alan firmaların finansal tablolarını nasıl etkiledi?. Dumlupınar Üniversitesi Sosyal Bilimler Dergisi, 18. 
Akdoğan, N. (2010). KOBİ finansal raporlama standardına genel bakış ve tam set IAS/IFRS'lerden farklılığı. Muhasebe ve Denetime Bakış Dergisi, 30, 1 -26.

Altıntaş, T. \& Parlak, N. (2018). A comparison of financial instruments between the Turkish financial reporting standards (TFRS) and financial reporting standards for large and medium-sized entities (BOBİ FRS). International Journal of Scientific and Technological Research, 4(10), 539-550.

Ayc1, Ali. (2012, Haziran). KOBI'lerin rekabet gücünün arttırllmasında uluslararası muhasebe standartlarına uyum sürecinin değerlendirilmesi. II. Uluslararası Türk Coğrafyasında UFRS Sempozyumu’nda sunulan bildiri, Karadeniz Teknik Üniversitesi, Trabzon, 25-42.

Bahadır, O. (2012). KOBI'ler İçin UFRS/TFRS kapsamında temel finansal araçlar: muhasebeleştirme ve ölçüm, Mali Çözüm Dergisi, $111,43-60$.

Büyük ve Orta Boy İşletmeler İçin Finansal Raporlama Standardı (BOBİ FRS), KGK.

Çalış, Y.E. ve Hışman, B. (2019). Hasılatın TFRS 15 müşteri sözleşmelerinden hasılat standard1, BOBİ FRS bölüm 5 ve vergi kanunlarına göre karşılaştırmalı incelenmesi. Ístanbul Aydın Üniversitesi Dergisi, 11(4), 355-377.

Çelik, O. (2010). Küçük ve orta büyüklükteki işletmeler için uluslararası finansal raporlama standardı: ne zaman ve nasıl?. Muhasebe ve Denetime Bakış Dergisi, 30, 41-56.

Çetinkaya, N. (2010). KOBI'ler için uluslararası finansal raporlama standardı ve Türkiye uygulaması. (Yüksek Lisans Tezi). Ankara Üniversitesi Sosyal Bilimler Enstitüsü, Ankara.

Demir, V. ve Bahadır, O. (2014). Yeni avrupa birliği yönergesi (2013/34 EU) kapsamında bireysel finansal tablolar. Mali Çözüm Dergisi, $121,13-33$.

Eksin, İ. (2013). KOBI'lerin gerçeğe uygun değer ile finansal raporlanmast ve bir turizm işletmesinde uygulama. (Doktora Tezi). Trakya Üniversitesi Sosyal Bilimler Enstitüsü, Edirne.

Ergi, Ş. ve Güleç, Ö.F. (2019). Büyük ve orta boy işletmeler için finansal raporlama standardı (BOBİ FRS): muhasebe uygulayıcılarına yönelik bir araştırma. Hitit Üniversitesi Sosyal Bilimler Enstitüsü Dergisi, 12(2), 377-399.

Fidan, M.E. ve Cinit, H. (2013). Muhasebe meslek mensuplarının mesleki tecrübeleri ile muhasebe standartlarına yönelik algıları arasındaki ilişki üzerine bir araştırma: marmara bölgesi örneği. Muhasebe ve Finansman Dergisi, 60, 1-25.

FRS 102, The Financial Reporting Standard applicable in the UK and Republic of Ireland (2015, Eylül). UK Financial Reporting Council. FRS 105, The Financial Reporting Standard applicable to the Micro-entities Regime, (2018, Mart). UK Financial Reporting Council.

Gençoğlu, Ü.G. (2020). Küçük ve mikro işletmeler için finansal raporlama standardı taslağı'nın BOBİ FRS ve vergi uygulamalarımız ile karşılaştırılması ve genel değerlendirme. Business and Economics Research Journal, 11(1), 187 -199.

Gökçen, G., Öztürk, E. ve Güleç, Ö.F. (2018). BOBİ FRS ve TFRS’nin finansal raporlara etkileri açısından karşılaştırılması. Finans Ekonomi ve Sosyal Araştırmalar Dergisi, 3(2), 437-457.

Gökçen, G., Öztürk, E. ve Güleç, Ö.F. (2019). KÜMİ FRS seti taslağ1, BOBİ FRS seti ve tam set TMS/TFRS'nin temel konular açısından karşılaştırılması. Finans Ekonomi ve Sosyal Araştırmalar Dergisi, 4(3), 413-430.

Gönen, S. ve Demir, Ç. (2012). Vergi usul kanunu ve KOBİ TFRS bölüm 13 açısından stokların karşılaştırılması. Uluslararası Alanya Işletme Fakültesi Dergisi, 4(2), $163-171$.

Hatipoğlu, O. (2009). Türkiye'de uluslararası muhasebe standartları'nın gelişsimi, gerekliliği ve uygulanabilirliği üzerine bir araştırma. (Yüksek Lisans Tezi). Karadeniz Teknik Üniversitesi Sosyal Bilimler Enstitüsü, Trabzon.

İğde, M. (2013). KOBİ TFRS'ye göre finansal tabloların değerlendirilmesi ve bağımsız denetimi. (Yüksek Lisans Tezi). Atatürk Üniversitesi Sosyal Bilimler Enstitüsü, Erzurum.

İstanbul Serbest Muhasebeciler ve Mali Müşavirler Odas1. (2019, Eylül). Küçük ve mikro işletmeler için finansal raporlama standartlarl semineri. Erişim adresi, https://archive.ismmmo.org.tr/docs/seminernotlar/11092019/emresenturk.pdf

Karahan, M. \& Ayvalığlu, A.B. (2019). The differences between LMSE FRS and TFRS comparison and accounting on financial leasing transactions in Turkey. Muhasebe ve Finansman Dergisi, 1-14. 
Karaömer, Y. \& Özbirecikli, M. (2019). Effects of financial reporting differences in between BOBİ FRS and MSUGTon financial statement analysis: an investigation on financial structure ratios. Muhasebe ve Finansman Dergisi, (84), 233-250.

Kamu Gözetimi Kurumu. (2020, 18 Nisan). Küçük ve mikro işletmeler için finansal raporlama standardı taslağı. Erişim adresi: https:// kgk.gov.tr/ContentAssignmentDetail/3595/Ku\%CC\%88c\%CC\%A7u\%CC\%88k-ve-Mikro-I \%CC \%87s\%CC\%A7 letmeler-I\%CC\%87c\%CC\%A7in-Finansal-Raporlama-Standard $\% \mathrm{C} 4 \% \mathrm{~B} 1$.

Kamu Gözetimi Kurumu. (2020, 20 Nisan), 2017 faaliyet raporu. Erişim adresi: https://www.kgk.gov.tr/DynamicContentDetail/4102/ Y\%C4 \%B111\%C4\%B1k-Faaliyet-Raporlar\%C4\%B1

Kamu Gözetimi Kurumu. (2020, 20 Nisan), 2018 faaliyet raporu. Erişim adresi: https://www.kgk.gov.tr/DynamicContentDetail/4102/ Y\%C4 \%B111\%C4\%B1k-Faaliyet-Raporlar\%C4\%B1

Kılıç, M. \& Uyar, A. (2017). Adoption process of IFRS for SMEs in Turkey: insights from academics and accountants. Accounting and Management Information Systems, 16 (2), 313-339.

Kırkık, Ş., Coşkun, S. ve Coşkun, S. (2019). BOBİ FRS’nin muhasebe mesleğine etkisinin SMMM'lerin bakış açıları doğrultusunda değerlendirilmesi: Manisa ilinde bir uygulama. Uluslararası Muhasebe ve Finans Araştırmaları Dergisi, 1(1), 58-79.

Kıymetli Şen, İ. ve Özbirecikli, M. (2020). KÜMİ FRS'nin iş dünyasına sağlayabileceği yararlar: BOBİ FRS, TMS/TFRS ve mevcut muhasebe sistemi ile mukayeseli bir inceleme. Muhasebe Bilim Dünyası Dergisi, 1-19.

Kumar, E.P., \& Mohan, B. (2015). Origin and development of auditing. Paripex - Indian Journal of Research, 4(9), 43-46.

KOBİ’ler İçin Türkiye Finansal Raporlama Standardı Hakkında Tebliğ, Resmî Gazete Sayısı: 27746. (2010, 1 Kasım).

Küçük, E. (2018). Devlet teşviki kapsamındaki düşük faizli kredilerin BOBİ FRS açısından değerlendirilmesi. Muhasebe Bilim Dünyası Dergisi, 20(4), 761-784.

Muhasebe Enstitüsü. (2020, 10 Nisan). Illk UMS çevirileri. Erişim adresi: https://muhasebe.istanbul.edu.tr/tr/content/yayinlar-vecalismalar/turkiye'deki-ilk-ums-cevirileri

Resmi Gazete, 30138 Say1l, (2017, 29 Haziran)

Selvi, Y. ve Ercan, M. (2018). BOBİ FRS kapsamında “stoklar”. Muhasebe Enstitüsü Dergisi, 16(59), 47-57.

Şensoy, H.B. (2008). Uluslararası finansal raporlama standartlarının ortaya çıkışı ve gelişimi ile muhasebe standartlarının Türkiye'deki durumu. (Yüksek Lisans Tezi). Gazi Üniversitesi Sosyal Bilimler Enstitüsü, Ankara.

Tekbaş, İ. (2020, 15 Nisan). KGK tarafından açıklanan yerel finansal raporlama çerçevesi nedir?. Muhasebe TR. Erişim adresi: http:// www.muhasebetr.com/yazarlarimiz/ismailtekbas/009/

Türk Ticaret Kanunu, 6102 Sayılı.

UK FRC. (2020, 18 Nisan). New accounting standards offer simplification for micro-entities and small entities. Erişim adresi: https:// www.frc.org.uk/news/july-2015/new-accounting-standards-offer-simplification-for

Utku, B.D. ve Gürsoy, K. (2011). KOBİ’ler için Türkiye finansal raporlama standartlarının(KOBİ TFRS) tam set TFRS ile karşılaştırılarak değerlendirilmesi. Mali Çözüm Dergisi, 103, 19-42.

Yalkın, Y.K. \& Demir. V. \& Demir, L.D. (2008). International financial reporting standards (IFRS) and the development of financial reporting standards in Turkey. Research in Accounting Regulation, 20, 279-294. DOI:10.1016/S1052-0457(07)00216-0

Yıldırım, G. (2019). BOBİ FRS karşılıklar standardı ve uygulaması. IBAD Sosyal Bilimler Dergisi, 421-431. 


\section{EKLER}

\begin{tabular}{|c|c|c|c|}
\hline & KOBİ IFRS & BOBİ FRS & KÜMİ FRS \\
\hline & 1. Küçük ve Orta Büyüklükteki İşletmeler & - & - \\
\hline \multirow{5}{*}{1} & 2. Kavramlar ve Genel İlkeler & \multirow{5}{*}{$\begin{array}{l}\text { 1. Kavramsal Çerçeve ve Finansal } \\
\text { Tablolar }\end{array}$} & 1. Kavramlar ve Genel İlkeler \\
\hline & 3. Finansal Tabloların Sunuluşu & & 2. Finansal Tabloların Sunumu \\
\hline & 4. Finansal Durum Tablosu & & 3. Finansal Durum Tablosu \\
\hline & $\begin{array}{l}\text { 5. Kapsamlı Gelir Tablosu ve Gelir } \\
\text { Tablosu }\end{array}$ & & \multirow{2}{*}{ 4. Kar veya Zarar Tablosu } \\
\hline & $\begin{array}{l}\text { 6. Özkaynak Değişim Tablosu ile Gelir ve } \\
\text { Dağıtılmamış Karlar }\end{array}$ & & \\
\hline & 7. Nakit Akış Tablosu & 2. Nakit Akış Tablosu & - \\
\hline \multirow[t]{2}{*}{2} & 8. Finansal Tablo Dipnotları & 26. Dipnotlar & 21. Dipnotlar \\
\hline & $\begin{array}{l}\text { 9. Konsolide ve Bireysel Finansal } \\
\text { Tablolar }\end{array}$ & 22. Konsolide Finansal Tablolar & - \\
\hline 3 & $\begin{array}{l}\text { 10. Muhasebe Politikaları, Tahminler ve } \\
\text { Hatalar }\end{array}$ & $\begin{array}{l}\text { 3. Muhasebe Politikaları, Tahminler ve } \\
\text { Yanlışlıklar }\end{array}$ & $\begin{array}{l}\text { 5. Muhasebe Politikaları, Tahminler ve } \\
\text { Hatalar }\end{array}$ \\
\hline \multirow{3}{*}{4} & 11. Temel Finansal Araçlar & \multirow{3}{*}{ 9. Finansal Araçlar ve Özkaynak } & \multirow{3}{*}{ 10. Finansal Araçlar ve Özkaynak } \\
\hline & 12. Diğer Finansal Araçlar & & \\
\hline & 22. Borçlar ve Özkaynak & & \\
\hline \multirow[t]{4}{*}{5} & 13. Stoklar & 6. Stoklar & 8. Stoklar \\
\hline & 14. İştiraklerdeki Yatırımlar & 10. İştiraklerdeki Yatırımlar & - \\
\hline & 15. İş Ortaklıklarındaki Paylar & 11. Müşterek Girişimlerdeki Yatırımlar & - \\
\hline & 16. Yatırım Amaçlı Gayrimenkuller & 13. Yatırım Amaçlı Gayrimenkuller & - \\
\hline 6 & 17. Maddi Duran Varlıklar & 12. Maddi Duran Varlıklar & 11. Maddi Duran Varlıklar \\
\hline 7 & $\begin{array}{l}\text { 18. Şerefiye Dışındaki Maddi Olmayan } \\
\text { Duran Varlıklar }\end{array}$ & 14. Maddi Olmayan Duran Varlıklar & 12. Maddi Olmayan Duran Varlıklar \\
\hline 8 & 19. İşletme Birleşmeleri ve Şerefiye & 21. İş Birleşmeleri & 19. İşletme Birleşmeleri \\
\hline 9 & 20. Kiralamalar & 15. Kiralamalar & 13. Kiralamalar \\
\hline 10 & $\begin{array}{l}\text { 21. Karşılıklar, Koşullu Borçlar ve } \\
\text { Koşullu Varlıklar }\end{array}$ & $\begin{array}{l}\text { 19. Karşılıklar, Şarta Bağlı } \\
\text { Yükümlülükler ve Şarta Bağlı Varlıklar }\end{array}$ & $\begin{array}{l}\text { 17. Karşılıklar, Şarta Bağlı } \\
\text { Yükümlülükler ve Şarta Bağlı Varlıklar }\end{array}$ \\
\hline 11 & 23. Hasilat & 5. Hasilat & 7. Hasilat \\
\hline 12 & 24. Devlet Teşvikleri & 16. Devlet Teşvikleri & 14. Devlet Teşvikleri \\
\hline \multirow[t]{2}{*}{13} & 25. Borçlanma Maliyetleri & 17. Borçlanma Maliyetleri & 15. Borçlanma Maliyetleri \\
\hline & 26. Hisse Bazlı Ödemeler & - & - \\
\hline \multirow[t]{2}{*}{14} & 27. Varlıklarda Değer Düşüklüğü & 18. Varlıklarda Değer Düşüklüğü & 16. Varlıklarda Değer Düşüklüğü \\
\hline & 28. Çalışanlara Sağlanan Faydalar & - & - \\
\hline 15 & 29. Gelir Vergileri & 23. Gelir Üzerinden Alınan Vergiler & 20. Gelir Üzerinden Alınan Vergiler \\
\hline \multirow[t]{2}{*}{16} & 30. Yabancı Para Çevrim İşlemleri & 20. Yabancı Para Çevrim İşlemleri & 18. Yabancı Para Çevrim İşlemleri \\
\hline & 31. Yüksek Enflasyon & $\begin{array}{l}\text { 25. Yüksek Enflasyonlu Ekonomilerde } \\
\text { Finansal Raporlama }\end{array}$ & - \\
\hline \multirow[t]{2}{*}{17} & $\begin{array}{l}\text { 32. Raporlama Döneminden Sonraki } \\
\text { Olaylar }\end{array}$ & $\begin{array}{l}\text { 4. Raporlama Döneminden Sonraki } \\
\text { Olaylar }\end{array}$ & $\begin{array}{l}\text { 6. Raporlama Döneminden Sonraki } \\
\text { Olaylar }\end{array}$ \\
\hline & 33. İlişkili Taraf Açıklamaları & - & - \\
\hline 18 & 34. Özellikli Faaliyetler & 7. Tarımsal Faaliyetler & 9. Tarımsal Faaliyetler \\
\hline \multirow[t]{2}{*}{19} & \multirow[t]{2}{*}{ 35. KOBİ IFRS'e Geçiş } & $\begin{array}{l}\text { 8. Maden Kaynaklarının Aranması ve } \\
\text { Değerlendirilmesi }\end{array}$ & \multirow[t]{2}{*}{ 22. KÜMİ FRS'ye Geçiş } \\
\hline & & 27. Geçiş Hükümleri & \\
\hline & & 24. Ara Dönem Finansa Raporlama & \\
\hline
\end{tabular}


